\title{
Newspapers as Political Instruments in Media Policy Debate
}

\section{Peter Putnis}

I

s press coverage of media issues self-interested? The short answer is yes, most of the time. There can be apparent exceptions. For example, a recent two 1 page feature by Luke Collins in The Australian Financial Review ('The Hilmer Report - Downgrade adds to pressure', 23 March 2001) gives great prominence to Fairfax chief Fred Hilmer's announcement downgrading profit forecasts and, all in all, appears to give Fairfax a rather hard time. It duly notes that Fairfax shares had fallen some 43 per cent over the last twelve months and that its Internet arm lost $\$ 40$ million in 1999-2000. It publicises criticisms of Hilmer's strategy by fund managers and even refers to a 'not warm and friendly' meeting between Hilmer and major Fairfax shareholder James Packer, discussion of which would, one might assume, embarrass Fred Hilmer. The piece is crafted with a keen sense of balance. Comments by Fairfax executives are carefully counterpointed by criticisms of Fairfax strategy and performance from various analysts. We are even told that the views of the chief executive of News Ltd, John Hartigan, were sought but that he declined to be interviewed. What could be fairer? Yet even in this admittedly highly professional piece the disinterestedness is more apparent than real. The crafted balance and tone of impartiality, worthy though they are, are themselves mobilised to give credibility to an article which is essentially a defence of Fairfax and of Hilmer's management.

Fairfax's recent performance and adverse comments on it were, after all, already on the public record. The article, while acknowledging them, is primarily a rebuttal with Hilmer given the dominant voice. The strategy is a subtle one, at least when compared with News Ltd's previous frontal attack on Fairfax in The Daily Telegraph which ran a story, including colour photographs of Fairfax executives playing golf during what The Daily Telegraph described as a 'crisis conference', that described Fairfax circulation as 'plummeting'. But The Australian Financial Review story is nevertheless a strategic intervention serving the interests of Fairfax management and shareholders.

You may suppose that when newspapers report on their own performance and that of their rivals, we can expect self-interest to colour editorial judgement both with respect to what is deemed worthy of coverage and how it is treated. Reports of audited circulation figures are interesting in this regard. Of 52 stories concerning newspaper circulation and readership published between 1997 and

Peter Putnis is Pro Vice-Chancellor, Division of Communication and Education at the University of Canberra. 
2000 by newspapers that can be checked via Dow Jones ${ }^{1}, 41$ carried positive headlines, six were neutral and only five were negative. This is despite the fact that the per capita circulation of newspapers continues to steadily fall. Since 1951 the weekly circulation of Australian newspapers has declined from 2.5 to 1.2 per head of population (Dermott, 1998).

For The Age it took only a 1.84 per cent increase in weekday circulation over a particular accounting period in 2000 to warrant the headline 'Surge in weekday sales of the Age' while the information that its Saturday edition declined by 3.03 per cent is given well down in the story (The Age, 4 August, 2000). When, in the six months to March 30, 1999, the Age's weekday sales dropped by 5.05 per cent (admittedly, in a period of savage discounting by News Ltd's The Australian), the paper played down circulation figures instead turning to less precise estimates of 'readership' in order to claim growth ('Newspaper readership growing across all titles' The Age, 21 May 1999).

Between 1996 and 2000 the weekday circulation of The Age fell from 205,000 to 190,864 , a fall of 9.3 per cent while its Saturday circulation fell from 350,000 to 309,478 or 8.8 per cent. Yet eleven of its eighteen stories about its circulation published between 1997 and 2000 featured headlines emphasising growth, via a selective highlighting of short-term variations. Of course The Age is not alone in this kind of positive spin. Sydney's The Sun-Herald proclaimed itself 'Australia's No 1' and 'Australia's greatest newspaper success story' when its circulation rose to over 600,000 in 1998 conveniently ignoring its rival Sunday Telegraph's circulation of over 700,000 (26 April, 1998). For its part News Ltd has been accused of 'mendacious propaganda' in its promulgation of circulation claims arising from its price cutting strategies (The Sydney Morning Herald, 29 April, 1998).

\section{Conflict of Interest and Media Power}

Criticising newspapers for reports on their own circulation may be somewhat carping. After all, in stories directly about themselves or their rivals the potential conflict of interest is evident to all and readers can make their own judgement. This is not the case in coverage of other aspects of the media and, in particular, of media policy. On the same day that The Australian Financial Review published its story about Fred Hilmer's management, The Daily Telegraph took a further editorial swipe against Government policy on the introduction of digital television, alleging that the Government had given between $\$ 5$ billion and $\$ 10$ billion worth of digital spectrum gratis to free-to-air broadcasters and introduced 'a host of restrictions to guarantee datacasters could not compete against existing networks'. Government policy was making Australia a 'digital backwater' and 'Prime Minister John Howard and Senator Richard Alston, his misinformed

1 The Dow Jones database includes The Age, The Australian, Financial Review, Canberra Times, Sun Herald, Sunday Age, Sydney Morning Herald, West Australian and The Newcastle Herald. 
Communications Minister, should hang their heads in shame' having 'robbed taxpayers of billions of dollars' ('High price for a last opportunity', 23 March, 2001).

The Daily Telegraph presents itself here as a fearless advocate of the public interest. Its strong language expresses outrage that Australian citizens are losing out because of Government ineptitude or worse. But whatever the cogency of this position, might it not have been fair for The Daily Telegraph to point out that News Ltd, as a would be broadcaster and datacaster, has a very strong direct interest in this particular Government policy? Should not readers be given the wherewithal to assess the range of motivations behind News Ltd's determined campaign to punish the Government for media policies it regards as detrimental to its interests? The Australian Press Council's Statement of Principles states that, 'A publication is justified in strongly advocating its own views on controversial topics provided that it treats its readers fairly by ... disclosing any commercial or other interest which might be construed as influencing the publication's presentation of news or opinion' (Australian Press Council, 1999a:176). Surely some explicit disclosure of interest was appropriate in the case in point or do editors assume that readers are so savvy (or cynical) that they expect conflict of interest as 'par for the course', hence obviating the need for explicit disclosure?

Media bullying of Governments and Oppositions appears to be becoming ever more blatant. Consider, for example, the opening segment of a recent John Laws show, and the way it sets the agenda for that day's program. Laws disparagingly comments on a recent statement by Kim Beazley that corporate executive salaries in Australia needed to be kept in check. Laws' message is clear - butt out of this issue; executives deserve what the market is willing to pay and, besides, its private money unlike publicly funded Parliamentary superannuation. He follows up with this warning: 'So Kim while you're looking at the big end of town's salaries - that might sound good - might make you feel good - might make people who don't like tall poppies feel good too if you're going to start criticising it. But you start criticising that and we'll get back onto Parliamentary superannuation for you and we'll have a game with that' (2CC, 29 March, 2001).

The issue of how the media use their power to pursue their own interests and the extent to which this cuts across the public interest in fair and balanced reporting is a wide-ranging one. It goes beyond specific instances to the wider influence of commercial judgement on news values. Michelle Grattan has commented that in Australian newspapers 'commercialisation has come into the ascendant as a core value' and that 'this has far-reaching implications for how our papers are run, how they look and what they contain - or do not contain' (Grattan,1998:1). She goes on to note (p. 13), by way of example, that News Ltd's

national and international interests are so vast that no day can pass when one bit of the empire is not faced with the task of reporting on other sections of the empire .... Newspapers fulminate about politicians' conflicts of interest. Yet a newspaper that is part of a 
conglomerate that runs a whole lot of other enterprises has perpetual conflicts of interest. The digital TV decision was a case in point where News' papers became weapons in the armoury. The coverage of Superleague was a particularly dramatic example.

Ewart (2000) reports that the problem is also severe in Australian regional newspapers noting that the convergence of newspapers' commercial and editorial sections means that 'journalistic independence and news sense are subsumed in favour of commercial imperatives' (p. 237) and that the media rarely make disclosures about commercial influences on news content (p. 239). The issue of commercial influence has, as Grattan and Ewart point out, enormous implications for the future of journalism.

Let us, however, return to the more specific case of press coverage of itself and of media policy. Assessing the quality of such coverage and the uses made of it has a particular importance since such assessment is germane to the efficacy of press self-regulation and of maintaining confidence in the processes of media policy development. Let us first turn to press self-regulation via the Australian Press Council.

\section{The Australian Press Council}

The Press Council, funded to the tune of $\$ 568,000$ by major publishers in 19992000 , is in the delicate position of having to balance its advocacy of a free press (which its benefactors characteristically identify with private ownership and freedom to pursue commercial interests without government interference) with its protection of the interests of individuals and groups whose rights might be infringed by the press. A former chair of the Press Council, Professor Pearce (Australian Press Council, 2000:11), has argued that there is no conflict between these two roles, commenting:

The function of the Council of monitoring and reporting on freedom of the press issues may at first sight seem incompatible with its complaints role. I have found this not to be the case. The two functions complement each other as the freedom of the press issues can form the basis from which it is possible to judge whether a publication has acted improperly.

But, of course, the potential conflict only disappears if one accepts, as does Professor Pearce, that 'freedom of the press' (variously interpreted) is the prior concern and therefore appropriately provides the framework from which to view complaints. The position, though defensible in terms of broad concepts of public interest, is rather counter-intuitive when it comes to individuals or groups who feel wronged by the press. The conflict is evident when Press Council rulings clash with those of other jurisdictions. When the Head of the Australian Palestinian Delegation felt wronged by a 1998 article in The Australian Financial Review he 
complained to both the Press Council and the NSW Administrative Appeals Tribunal. While the Press Council dismissed the complaint the Tribunal found that the article vilified Palestinians and contravened Australia's antidiscrimination laws. Despite the ruling the Press Council went on to criticise the Tribunal warning that its decision impeded press freedom.

The Press Council has recommended itself to government as a model of successful self-regulation. Its submission to the recent Inquiry into Media Regulation by the Senate Select Committee on Information Technologies was headed 'self-regulation works'. The Council 'expressed the view that its background and experience of the self-regulation of the print media would provide useful information to the committee. It asserted broadly that self-regulation had been shown to work for the print media and should be applied generally to the communications industries' (Press Council News, February, 1998). A cornerstone of the Press Council approach is a confidence in the willingness of newspapers to prominently publish findings critical of themselves. Furthermore the system is based on the view that the publication of an adverse finding constitutes an appropriate and sufficient remedy for the complainant. Underpinning all this is the traditional libertarian notion of a 'free market of ideas'. Another former Chairman of the Press Council, Professor David Flint (Australian Press Council, 1996:10), put the case in these terms:

We strongly believe that the best remedy to a wronged complainant is the prominent publication of an adjudication. As Justice Holmes argued, echoing Milton, the best test of truth is the power of the thought to get itself accepted in the competition of the market. A Press Council adjudication...allows aggrieved complainants to be vindicated in the eyes of the public.

Let us leave aside the issue of whether complainants would agree that mere publications of an adverse funding is the 'best remedy'. The more immediate question is whether Press Council interventions (making adverse findings and insisting on having them published) effectively redress what one must assume had been a kind of 'market failure'. There is much evidence to suggest that they do not do this simply because it is the newspapers themselves who control this particular marketplace. While it is true that both major newspaper groups, News Ltd and Fairfax, have committed themselves to report Press Council findings, they do so very much on their own terms. Consider, for example, the positioning of reports of adverse findings on selected front-page stories ${ }^{2}$ :

2 Press Council adjudications are published quarterly in Press Council News and republished in the Press Council's Annual Reports. The Reports also include data on the publication of adjudications in the press. 
- $\quad$ Adjudication No 910 (February 1997) upholding a complaint against a front page story and photograph in The Daily Telegraph was published on page 20;

- Adjudication No 924 (May 1997) against a front page Sunday Mail (Brisbane) story appeared on page 58;

- Adjudication No 945 (September 1997) against a front page article in The Sunday Telegraph appeared on page 48;

- Adjudication No 960 (February 1999) against a front page article in The Herald Sun (Melbourne) appeared on page 26, and

- Adjudication No 1057 (November 1999) against Sydney's Sun Herald appeared on page 55 .

The Press Council has emphasised that it 'reviews the publication of adjudications at each meeting to ensure they are published and published with appropriate prominence' (Press Council News, May 1998:3). One can assume, then, that the pattern indicated above is judged by the Press Council to meet its requirements. Even so, it has in recent years faced direct challenges to these rather minimalist requirements. The Townsville Bulletin republished a photograph, which the Council found irresponsible, next to the publication of the Council's adjudication and accompanied by editorial comment rejecting the Council's findings. The Daily Telegraph also republished 'sneak photographs' of the then Senator Bob Woods and his wife, which had been the subject of an adverse finding in 1997, in the context of publicising a merit award won by the press photographer who had taken the photo. In 1999 The Australian refused to publish an adverse adjudication on the grounds of alleged procedural unfairness and for a time refused to cooperate with the Council.

In condemning the republication of The Townsville Bulletin photograph the Council saw fit to remind editors that this kind of action risked undermining the principles of self-regulation. By challenging Press Council rulings the press could be its own worst enemy. Such challenges could be used as evidence of the failure of self-regulation and for the need for some form of statutory intervention. They are also a symptom of a deeper problem.

The Press Council makes a valuable contribution to debate on the media in Australia. Its adjudications thoughtfully articulate an important position derived from its primary concern with press freedom. It is not, however, well positioned to counter the power of the press when the press chooses to pursue its own interests. The former Chairman, Professor Pearce, noted that the Council had 'given careful consideration to its submissions on important issues so that it does not simply assume a lobbyist role but presents the case from the viewpoint of the public interest' (Australian Press Council, 2000:9). However, in order to maintain that the Council can effectively be both a lobbyist for existing newspapers and defend the public interest requires an unrealistically sanguine view of Australia's current press system (dominated, of course, by two corporations) and the imperatives that drive it. This is further evident if we look specifically at press reporting of media policy questions that affect it. 


\section{The Interdependence of Politics and the Media}

As a preliminary point it should be noted that the interdependence of politics and the media renders media policy making a particularly fraught and contentious process. Governments and political parties have a much greater direct interest in the structure and day to day functioning of the media than they do in other industries, say tourism, manufacturing or mining — they are prime users of the media; they crave media support; and their political fortunes are influenced by media reporting. Individual politicians are dependent on the media to promote their status as public figures. At the same time, they can suffer at the hands of the media via encroachments on their privacy.

It is hardly surprising, then, that governments and politicians are not seen as disinterested parties when it comes to developing media policy. Bowman (1988) and Chadwick (1989) argued that in the 1980s the Labor government established mutually rewarding links with Rupert Murdoch and Kerry Packer whereby favourable media coverage was rewarded by cross media ownership rules that favoured the Murdoch and Packer camps. Barr (2000:10) comments that, 'the history of Australia's pattern of media ownership and control shows extraordinary political favouritism and pragmatism on the part of governments towards media corporations judged to best serve the party's interests.' Papandrea (2000:12) has noted that government decisions on digital television have illustrated the propensity of politicians to bow to media pressure: 'Our political system gives the ultimate power for the licensing of broadcasting to politicians whose own shortterm interests are more likely to be better served by keeping powerful media proprietors friendly. Fearing a political payback, politicians have been reluctant to introduce policies potentially detrimental to the commercial interests of established players'. At the more personal level, politicians as public figures are more likely to have direct experience of media intrusion than the average person. Moreover, the political consequences for individual politicians publicly sullied in the media can be amplified. This arises because the strong party adherence characteristic of Australian politics leads to damnation by association and hence affects party standing as a whole. Recognition of such consequences might well colour attitudes to the efficacy of codes of practice and prompt calls for their review.

The threat of 'political payback' for the advocacy of policies seen by the media as detrimental to their interests is a quite palpable one. If politicians are interested parties in media policy development, so too, of course, are the media themselves. Large sections of the media are dependent on supportive government policies for their economic well being and are willing to fight to maintain that well being. Furthermore there is a long standing concern that governments inevitably tend to accumulate power in their own self-interest and that therefore any talk of media regulation (other than regulation which favours established players) should be treated with great suspicion. Most importantly, the media are uniquely positioned, as compared to other industries, to use their public reach and influence to intervene in policy debates directly affecting them. They can influence public 
views (and if necessary foment dissent) on media policy and influence public respect for governments and politicians. When it suits them, the media can 'flex their muscles' to ward off unwelcome government attention by direct appeals to the public which also serve as a veiled political threat, demonstrating as they do, their power to the government of the day. Media commentator Dennis Shanahan (2000:30) has gone so far as to say that when it comes to media policy 'both sides of politics ... have allowed a cringing culture towards media organisations and their related businesses to develop'. Other lobby groups need to hire PR professionals in order to obtain favourable media coverage. The media themselves have almost unlimited media resources at their disposal.

\section{Proposed Media Complaints Commission}

As argued by Ward (1995:126), while it may be generally true that 'the penchant of proprietors blatantly to use their newspapers as political instruments' has diminished 'under the weight of commercial pressures to build and maintain large heterogeneous audiences', this is not the case when media interests themselves are directly challenged by media policy proposals. Then, there are few holds barred. This can be seen if we examine media responses to the recent Senate Select Committee Report, In the Public Interest: Monitoring Australia's Media (2000, - hereafter referred to as 'Report') which recommended the establishment of a single statutory Media Complaints Commission (MCC) covering the press as well as broadcasting. Needless to say this proposal to bring broadcast and press regulation under the same umbrella sparked outrage amongst press interests who labelled it as an outrageous encroachment on press freedom. Somewhat paradoxically (and unfortunately) the extreme nature of the response seemed to provide further ammunition to those who see the need for more effective checks on media power, rather than providing an effective defence of press freedom.

The Report was tabled in the Senate on 13 April 2000. Its main recommendation was that the Government establish an 'independent statutory body, known as the Media Complaints Commission' in order to 'more effectively protect the right to privacy and empower individuals in lodging a complaint against Australia's information and communication industries' (Report:xii). The MCC would provide a one-stop shop for all complaints and would also function as a final adjudicatory body for complaints. It would work in conjunction with the existing industry-based complaints bodies and procedures.

The Committee found that self-regulation in the print media was 'failing the community' and that the community was confused by the different complaints procedures for different media and industries. In general it found that 'the complaints handling procedures and regulatory codes in [all media] sectors are inadequate, and need to be simplified and strengthened' (Report:128). It also found that 'the complexity involved in making a complaint and the perception of an inadequate outcome, may discourage individuals from engaging in existing complaints handling procedures' (Report:134). 
Despite the majority Report's clear and forceful recommendations regarding the MCC, the Report was presented to Parliament by its Chair, Senator Jeannie Ferris (Liberal, South Australia), with something less than outright endorsement. Senator Ferris noted that the Report was about the protection of the media and the protection of consumers and that 'this Report seeks to put in place a means by which consumers can effectively complain about ... breaches'. However she went on to say that she 'would be delighted if the recommendations in the Report ... particularly for a Media Complaints Commission, were never used because the media itself improved the efficiency and effectiveness of the complaints regime that already exists'. She remarked, somewhat enigmatically given that statutory intervention was being recommended, that 'the Report provides an opportunity for improvements to be made to the self-regulation of Australia's media' (Commonwealth Parliamentary Debates, 2000). The tenor of this speech suggests that there was little expectation that the Government would actually proceed to establish a Media Complaints Commission. Rather it seemed to be sending the message that the media should improve its self-regulatory procedures so as to render such a commission unnecessary while at the same time waving (albeit somewhat weakly) the 'big stick' of government intervention. The vast majority of the press, however, saw no need whatsoever to take the hint.

It should be noted that there had been a measure of political self-interest in the setting up of this Inquiry. When the Committee began its deliberations in 1997 media/political relations were at a particularly low ebb. Unwritten codes of secrecy between politicians and gallery journalists that protected privacy of personal relationships had been challenged by the 'Woods affair'. The obsessive media tracking of Senator Colston had also raised political and public sensitivities.

One of the major political issues of 1996 and 1997 was the so-called 'travel rorts' affair in which a number of politicians on both sides of parliament were investigated for dishonest travel claims. The investigations and their reporting inevitably created tensions between politicians and the media. These came to a head when The Daily Telegraph, (7 February 1997) published the sneak photographs (noted earlier) of Liberal Senator Bob Woods (who as well as being investigated for 'travel rorts' was involved in a family crisis) and his wife Jane in private discussion in the backyard of their home with the headline: 'In the garden of their home, a Senator and his wife confront a scandal'. A complaint about the story was upheld by the Press Council (Australian Press Council, Adjudication No. 916, April 1997). While The Daily Telegraph published the adjudication (16 April 1997:22) it challenged it in an editorial on the same day, (p. 10) on the basis that both Senator Woods and his wife were public figures. The Daily Telegraph's unrepentant stance would have irked Senators. Certainly this particular case featured prominently in the Report. Also noteworthy in this regard was the extensive quoting in the Report of the response by Lord Wakeham, Chair of the United Kingdom Press Complaints Commission, when informed by the Committee of the The Daily Telegraph's republishing of the photograph. Stating that no such blatant dismissal of the self regulatory adjudications had ever 
happened in the United Kingdom, Wakeham's quoted response in the Report ( $\mathrm{p}$. 35) asserted:

We are there to run a code that they ask us to. If they are not going to obey it, the system would break down and the government would have to act, and the newspaper industry does not want this to happen.

In the same period Senator Colston became the target of intense political scrutiny, especially over 'travel rorts', not least because his move from the ALP to Independent had made him a powerful player in the passing of Senate legislation. It is noteworthy that a submission from his wife, Mrs D. Colston, features prominently in the Report as evidence of unacceptable media intrusion.

Is it reasonable to infer that the media treatment of Senators Woods and Colston was a factor in the decision by the Senate Select Committee of Information Technology to launch an inquiry and that it was driven by specific political as well as more general public interest concerns. The political genesis of the Inquiry does not, however, negate the public interest importance of the issues of media accountability that it addressed.

\section{The Press Council Response}

The Press Council would not have been surprised by the Report's recommendation to establish a statutory Media Complaints Commission. It is clear from the Press Council's final submission to the inquiry that the Committee had canvassed with it the possibility of the Press Council extending its powers so that, in the Committee's view, it could become a more effective regulator. However the Press Council rejected this possibility commenting that it is 'established and funded by the print media' and that 'its power in relation to the receipt and determination of complaints is that which is given to it by the media which established it' and further that 'it is most improbable that the print media in Australia would agree to the extension of the Press Council's power' and any such suggestion 'is unlikely to result in any positive response'. The Press Council (Australian Press Council, 1999b:1459) went on to suggest a possible course of action for the Committee but at the same time warned it against taking such action:

Accordingly, if the committee were to consider it desirable for additional power to be given to a body to deal with print media it would be necessary for the committee to recommend legislation to establish a statutory body and invest it with whatever are considered to be appropriate powers. It should be recognised that such a step would bring the status of the print media in this country to that in countries where there is no freedom of the press. In particular, it would place Australia at risk of being classed amongst those countries where the expression of critical opinion by the press may attract political or economic sanctions. 
The message was clear: leave us alone or we will play our 'freedom of the press' card and we will play it hard. One can speculate that this Press Council response painted the Committee into something of a corner. The statutory Complaints Commission became a recommendation, albeit one presented by the Committee Chair to Parliament in a way tinged with regret that the press itself could not have been more responsive to the problems the Committee saw in its self-regulatory practices.

\section{Press Response}

Press response to the Report was swift, short, and sharp. Editorial response can be regarded as extraordinary in both its consistency and in the large number of leading national and state papers that chose to comment. Editorials on the Report appeared in the Sydney Morning Herald, The Australian, The Daily Telegraph, The Herald Sun, the Courier Mail, the Adelaide Advertiser, the Canberra Times, and the Age. Editorials, which unanimously condemned the Report's findings, in particular the concept of a statutory Media Complaint Commission, were a clear warning to Government that it interfered with the press at its own peril. The flippant and dismissive terminology that pervaded news reports and editorials detracted from press claims that their arguments were based on high principle, motivated by the defence of freedom of speech in 'the public interest'. Rather, they displayed a 'cockiness' born, one assumes, of a confidence that the Senate Report could be summarily dismissed with impunity and by a desire to send a clear message to Government about press prerogatives. Rather than accept the Report as a warning that it should get its house in order, a reading promoted by Senator Ferris in her speech presenting the Report to Parliament, the press chose (injudiciously, perhaps) to ridicule it.

The tenor of response was set by a press release from the Press Council (General Press Release No 238, 13 April 2000) which dismissed the Report as 'silly' though 'attractive to many politicians as it enables avoidance of public attention relating to their affairs'. These words were given great prominence as the headlines in The Australian, 'Media report a "silly" read' (14 April 2000:5), and in the Sun Herald, "Gripes body "silly" (18 April 2000:14) indicate. The AAP reports were also influential in developing the tone of news response, with all three of them describing the MCC as a 'one stop shop for media gripes, to be funded by taxpayers'. Although not technically an inaccurate term, 'gripes' carries an innuendo of unwarranted complaint and its use suggested a diminished respect for complainants, public and/or political. Its use in ostensibly 'straight reporting' suggests an unwillingness by the media to impartially report criticisms of itself even when made by a Senate Committee. 'Gripes' was repeatedly used in the many press reports based on the AAP story.

Editorial response to the Report was designed to send a clear and forceful message to Government: the recommendations of the Report should be shelved. The Daily Telegraph editorialised, 'put simply, in a democracy, government has 
no role to play in media if this sector is to remain independent. This proposal is intrusive and a dangerous step along an authoritarian path' (19 April 2000).

The Australian talked of 'the slippery path to authoritarianism' and referred to the creation of a 'Ministry of Truth' and asserted that 'the authoritarian mind can always find reasons for wanting to "improve" methods of control' (14 April 2000). Political self-interest was a central theme of attack in editorials. Newspapers were openly contemptuous of Government interference. The only qualification offered in some was the acknowledgment that their arguments might read as 'self interest' but the assertion was that they were motivated by 'public interest'. The Australian noted that it was fortunate that 'the Committee's undemocratic recommendations faced some serious obstacles'. Firstly, the editor claimed, it was 'doubtful whether the Commonwealth has the power to control the print media', claiming incorrectly that this issue is not discussed in the majority report. Its second argument was even more disparaging, attacking the political intellect of the Committee while registering a division between its members and noting 'wiser heads more dedicated to preserving our freedoms'. Admitting to having had problems with the Prime Minister, John Howard, and the Communications Minister, Richard Alston, The Australian asserted that it doubted that either of these members of the executive would fail in their "commitment to our fundamental democracy. We assume the Committee's Report will be dutifully read - and dutifully filed where it belongs'. The warning was specific, targeting those the paper or proprietors would hold responsible for acceptance of any of the Committee's recommendations.

\section{Political-Press Stand-off}

To date, there has been no formal Government response to the Report. Despite the general undertaking of Government to respond to committee reports within three months, the Government has not yet responded at the time of writing, one year later. The media response may preclude that eventuality. The publication of two letters from the Chair of the Committee represent one of the few indications of public recorded 'debate' on the Report. The fact that it represented debate between press and politician only further emphasises the difficulty for the public to see the link between their interests and this political/media scuffle. The letters were published in the Canberra Times (19 April 2000:10) where Ferris was once a journalist, and in the Adelaide Advertiser (22 April 2000:20). The Adelaide Advertiser's editorial, like the editorials of other papers, had resorted to alarmist sensationalism in its response to the Report, describing the Report as 'ironic, sad and reprehensible' and its recommendation as 'the thin end of a mighty fat wedge, the first step on the descent to the Orwellian hell of Ministry of Truth' (15 April 2000:20). Ferris's reply used the categories 'ironic, sad and reprehensible' to criticise the response: 'These are very much the words that can be used to describe the Editorial' (Adelaide Advertiser, 19 April 2000:10). She also took the opportunity to attack the credibility of the Australian Press Council noting the funding it received from major publishers. 
In the upshot it seems highly unlikely that the chief recommendation of the Report to establish a Media Complaints Commission will be acted upon by the current Government. The comments in editorials already cited clearly indicate that the expectation is that the Report will be 'shelved'. Whether this is a perspective based on inside information or a ploy to deflect or allow Government to ignore the Report is difficult to assess.

If the Report is unlikely to be implemented, as it appears, what is its significance? Its main importance is as a political threat, not to be acted upon now, but laid on the table as a warning to the media. The Inquiry, the Report and the media response to it are less significant with respect to immediate policy outcomes than for the insights they offer into media politics - its symbolic gestures, rhetorical positions, main actors and power plays. It is a politics where the press are far from dispassionate observers but are forceful players only too willing to use their ready access to electors to intimidate policy makers. But will the press eventually overreach? One suspects it will, given the arrogance it so often displays in response to criticism of its performance. If support grows for statutory intervention, surely an unwelcome development, the press will only have itself to blame. Certainly there is one ex-journalist, now a Liberal Senator, whose views on the press must surely have hardened considerably given her experience of chairing a committee which sought to make it more accountable.

\section{References}

Australian Press Council (1996), Annual Report No 20, 30 June 1996, Sydney.

Australian Press Council (1999a), Annual Report No 23, 30 June 1999, Sydney.

Australian Press Council (1999b), ‘Australian Press Council Submission', pp. 1458-1464 in 'Submissions to the Senate Select Committee on Information Technologies, SelfRegulation in the Information and Communications Industries', Vol. 8, (Senate Committee Working Papers).

Australian Press Council (2000), Annual Report No 24, 30 June 2000, Sydney.

Barr, T. (2000), New Media.com.au: The Changing Face of Australia's Media and Communications, Allen \& Unwin, St Leonards.

Bowman, D. (1988), The Captive Press, Penguin, Ringwood.

Chadwick, P. (1989), Media Mates, Sun Books, Melbourne.

Commonwealth of Australia (2000), Report by the Senate Select Committee on Information Technologies, In the Public Interest: Monitoring Australia's Media, Canberra.

Commonwealth Parliamentary Debates (Senate) (2000), 13 April:14034-6.

Dermott, B. and Associates (1998), 'The Status of Media Usage in Australia', Quarter R3 1997, Melbourne. 
Ewart, J. (2000), 'The Black and White Divide: More Like a Thin Grey Line', Media International Australia 95:237-258.

Grattan, M. (1998), 'Editorial Independence: An Outdated Concept?', Australian Journalism Monographs, No 1, University of Queensland, Brisbane.

Papandrea, F. (2000), Broadcasting Planning and Entrenched Protection of Incumbent Broadcasters, Institute of Public Affairs, Melbourne and the Communication and Media Policy Institute, University of Canberra.

Payne, T. and P. Putnis (2000), 'Media Coverage as Policy Intervention: The Senate Select Committee Report In the Public Interest: Monitoring Australian Media and the Media Response', paper presented to the Communication Research Forum, Canberra, October.

Shanahan, D. (2000), 'Latham Gambles on Packer — and Loses, The Weekend Australian, September 2-3:30.

Ward, I. (1995), Politics of the Media, Macmillan Education Australia, Melbourne.

The author acknowledges the contribution of Trish Payne, Lecturer in Political Communication, University of Canberra to this paper. The paper draws substantially on Payne and Putnis, (2000). The author gratefully acknowledges helpful comments by the Co-editor and two anonymous referees 